\title{
Note
}

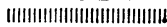

\section{Transfer of Cadmium through Placenta and Milk in the Mouse ${ }^{\dagger}$}

\author{
Mamoru TANAKa, Naonori Matsusaka, AkiraYuYama \\ and Haruo KoBAYASHI
}

Veterinary Pharmacology, Department of Veterinary Medicine, Faculty of Agriculture, Iwate University, Ueda, Morioka, Iwate

Received September 29, 1971

\section{Introduction}

In their radioautographic study, Berlin and Ullberg ${ }^{1)}$ observed no trace of cadmium in any fetus of a mouse injected intravenously with a single dose of ${ }^{109} \mathrm{Cd}$. Ferm, et al. ${ }^{2)}$ demonstrated, however, that cadmium was transmitted to the fetus, of the hamster. Schulert, et al. ${ }^{3)}$ confirmed this result by their experiment on rats. This paper deals with the transfer rate of radioactive cadmium $\left({ }^{115 m} \mathrm{Cd}\right)$ to the newborn mice through the placenta during their intrauterine life and through the dam's milk after birth. The relative contributions by the transplacental and milk-borne ${ }^{115 m} \mathrm{Cd}$ in the young during the nursing period were also investigated.

\section{Materials and Methods}

Adult female mice of the ICR strain were used in this experiment. Radioactive cadmium chloride $\left({ }^{115 m} \mathrm{Cd}\right.$, produced by the New England Nuclear Corporation) was adjusted to approximately $500 \mu \mathrm{Ci} / \mathrm{m} l$ (about $\mathrm{pH} \mathrm{5)}$ with distilled water, in which $150 \mu \mathrm{g}$ of stable cadmium was contained as carrier. The mice were fed a commercial diet and allowed to drink water ad libitum.

For timed mating, two or three female mice were put into a cage housing a male late in the afternoon and kept there overnight. When the presence of a vaginal plug was observed on the next morning, the gestation period began to be counted on that day, which was regarded as day 1 . The pregnant mice were then divided into two groups of five mice each; one was an intact control and the other a $\mathrm{Cd}$ group. The mice of the $\mathrm{Cd}$ group received $50 \mu \mathrm{Ci}$ of ${ }^{115 m} \mathrm{Cd}$ contained in $0.1 \mathrm{~m} l$ of solution intravenously some time between 24 and 36 hours prior to the expected parturition. After dosing, the whole-body counting was conducted by a small-animal scintillation counter with a 3 in. $\times 3$ in. $\mathrm{NaI}(\mathrm{Tl})$ crystal (SA-250, product of the Fujitsu Works, Tokyo). In both the control and the Cd groups, the mice delivered on the same day, and the radioactivities of the newborns at birth were assayed in the same manner as described above. The values. obtained from this assay were regarded as the amounts transferred from the dams to. their young through the placenta. All the dams of both groups were allowed to nurse ten newborns each. Immediately after the determination of radioactivity, five of the newborns of one group were exchanged with the same number of those of the other group, so that they might be nursed by the step. mother. This made it possible to determine (1) the amount of ${ }^{115 m} \mathrm{Cd}$ transferred to the newborns via the placenta, (2) the decreasing rate of this amount in these newborns when they were nursed by the intact control dams, and (3) the amount accumulated via

† This work was aided in part by Research Grant from the Ministry of Education. 
Table 1 Activity of ${ }^{115 m} \mathrm{Cd}$ at various times after birth expressed as a percentage of initial maternal activity

\begin{tabular}{cccccc}
\hline \multirow{2}{*}{$\begin{array}{c}\text { Days after } \\
\text { birth }\end{array}$} & $\begin{array}{c}\text { Mean uptake in } \\
\text { a newborn* }\end{array}$ & $\begin{array}{c}\text { Through } \\
\text { placenta }\end{array}$ & $\begin{array}{c}\text { Through } \\
\text { milk }\end{array}$ & \multicolumn{2}{c}{ Relative contribution } \\
\cline { 5 - 6 } 0 & $0.09 \pm 0.03$ & 0.09 & - & 100 & Placenta \\
1 & $0.14 \pm 0.06$ & 0.09 & 0.05 & 64.3 & 35.7 \\
3 & $0.21 \pm 0.09$ & 0.08 & 0.13 & 38.1 & 61.9 \\
5 & $0.26 \pm 0.10$ & 0.08 & 0.18 & 30.8 & 69.2 \\
7 & $0.29 \pm 0.11$ & 0.08 & 0.21 & 27.6 & 72.4 \\
10 & $0.33 \pm 0.13$ & 0.08 & 0.25 & 24.2 & 75.8 \\
14 & $0.38 \pm 0.13$ & 0.07 & 0.31 & 18.9 & 81.1 \\
17 & $0.30 \pm 0.11$ & 0.07 & 0.23 & 23.7 & 76.3 \\
21 & $0.19 \pm 0.08$ & 0.06 & 0.13 & 29.5 & 70.5 \\
28 & $0.13 \pm 0.04$ & 0.05 & 0.08 & 38.5 & 61.5 \\
35 & $0.13 \pm 0.04$ & 0.05 & 0.08 & 38.5 & 61.5 \\
\hline
\end{tabular}

* Mean of five litters \pm standard deviation

milk in the newborns nursed by the dams of the $\mathrm{Cd}$ group. The radioactivity of each newborn was determined at appropriate intervals until two weeks after weaning. The amount of ${ }^{115 m} \mathrm{Cd}$ in the newborn was expressed as percentage of the dose initially administered to the dam (hereinafter referred to as $\%$ of the dose).

\section{Results}

As shown in Table 1, the young born from the dams of the $\mathrm{Cd}$ group contained about $0.09 \%$ of the dose at birth. This value was regarded as the amount incorporated into each newborn during fetal life. The newborns increased significantly in ${ }^{115 m} \mathrm{Cd}$ content with the advance in age while they were nursed by the same dams. At 14 days of age, the cumulative amount of ${ }^{115 m} \mathrm{Cd}$ in these newborns reached a peak of around $0.4 \%$ of the dose. Then it decreased markedly as the weaning time approached (indicated by blank circles in Fig. 1). A slowly decreasing pattern was observed after weaning. The amount retained in these mice was 0.13 $\%$ of the dose at 35 days of age.

On the other hand, the young delivered by the dams of the $\mathrm{Cd}$ group and nursed by those of the control group showed a slowly decreasing pattern at a roughly constant rate for the first 17 days after birth. As the

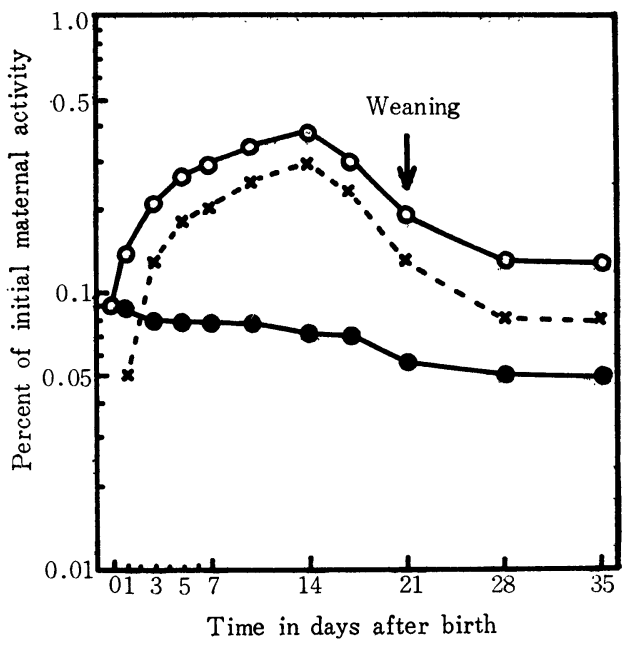

Fig. 1 Transfer of ${ }^{115 m} \mathrm{Cd}$ through placenta and dam's milk to newborn mice.

Cumulative amount of ${ }^{115 m} \mathrm{Cd}$ through placenta and milk

- Retention of ${ }^{115 m} \mathrm{Cd}$ through placenta

$\times$ Cumulative amount (calculated) of ${ }^{115 m} \mathrm{Cd}$ through milk

weaning time approached, a rather rapid decrease was observed transitionally and followed by a slow decrease again. Consequently, the ${ }^{115 m} \mathrm{Cd}$ content was around 65 $\%$ of the activity detected at birth in these mice at 35 days of age (indicated by solid circles in Fig. 1).

The cumulative amounts of ${ }^{115 m} \mathrm{Cd}$ originated from the dam's milk were calculated 
by subtracting the values of the third column from those of the second column in Table 1. The results obtained are shown in the fourth column. These calculated values were in fairly good agreement with those obtained by assaying from the young which were born from the dams of the control group and nursed by those of the $\mathrm{Cd}$ group as foster dams until weaning. The calculated values are plotted in Fig. 1 as a broken line. Twenty-four hours after birth, around $0.05 \%$ of the dose was found to have been transmitted to a newborn. In other words, around $0.5 \%$ of the dose was transmitted to a litter of ten in 24 hours. The cumulative amount increased markedly with the lapse of time, reached a peak 14 days after birth, and then decreased toward the time of weaning. It exhibited a gentle slope after weaning. The amount retained 35 days after birth was 0.08 $\%$ of the dose, which was approximately one-third of the highest value that was shown 14 days after birth.

Furthermore, relative contributions by the transplacental and milk-borne ${ }^{115 m} \mathrm{Cd}$ taken by the newborns were estimated on the basis of the data presented in the third and fourth column of Table 1 . The results obtained are shown in the fifth and sixth column of Table 1 and Fig. 2. They have elucidated that the milk-borne ${ }^{115 m} \mathrm{Cd}$ had a larger relative contribution to the total amount of ${ }^{115 m} \mathrm{Cd}$ transmitted to the newborn mice than the transplacental one.

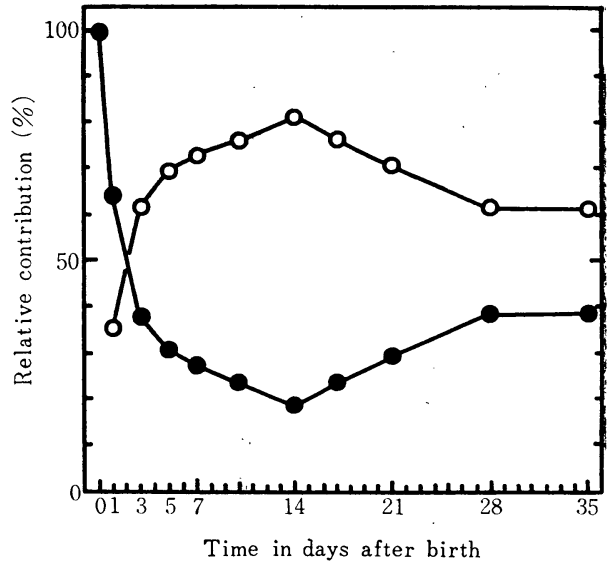

Fig. 2 Relative contributions by the transplacental and milk-borne ${ }^{115 m} \mathrm{Cd}$ taken by the newborn mice.

Contribution by milk-borne ${ }^{115 m} \mathrm{Cd}$

- Contribution by transplacental ${ }^{115}{ }^{m} \mathrm{Cd}$

\section{References}

1) Berlin, M., and S. Ullberg: Arch. environ. Health, 7, 686 93 (1963)

2) Ferm, V.H., D.P. Hanlon and J. Urban: J. Embryol. exp. Morph., 22, 107 13 (1969)

3) Schulert, A.R., S.R. Glasser, E.G. Stant, Jr., A.B. Brill, R.P. Koshakji and M.M. Mansour: In, Radiation Biology of the Fetal and Juvenile Mammal (eds. Sikov, M.R., and D.D. Mahlum), AEC Symposium Series 17, pp. 145 52 (1969) 